\title{
Migrations and diversifications in the UK and Japan
}

\author{
Jenny Phillimore ${ }^{1 *}$ (D), Gracia Liu-Farrer ${ }^{2}$ and Nando Sigona ${ }^{1}$
}

\author{
* Correspondence: j.a.phillimore@ \\ bham.ac.uk \\ ${ }^{1}$ Department of Social Policy, \\ Sociology and Criminology, \\ University of Birmingham, \\ Edgbaston, B15 2TT Birmingham, \\ UK \\ Full list of author information is \\ available at the end of the article
}

\begin{abstract}
Japan and the UK are long-established countries of immigration which although having different histories both share experience as colonial powers which have shaped their somewhat hostile attitudes towards migration alongside a need for migrant labour and negative public attitudes towards migrants. This paper sets the context to the Special Issue of the same name. It examines the migration and diversification histories and scholarships of Japan and the UK identifying common themes as well as divergences noting the ongoing diversifications of populations in both countries albeit on different scales. It then examines the key features which shape processes underpinning the emergence of superdiversity: super-mobility, and the scale, speed and spread of diversification, arguing the need to think about such processes outside of UK and Europe and considering the ways in which shifting scholarly gaze of superdiversity researchers to Japan can address some of the critiques of its Western-centric bias. The paper then outlines four main themes in superdiversity research setting out how they are addressed in this special issue before describing the key contributions of the ten papers which form the content of the collection.

Keywords: Superdiversity, Superdiversification processes, Japan, UK, Migration scholarship
\end{abstract}

\section{Introduction}

Both the UK and Japan have long-established immigrant communities the nature of which is somewhat shaped by centuries of colonial power and relations. Although these two countries have different immigration histories in the post-war era, and other political, economic and social differences, they share the challenges brought by the dilemma of labour and skills shortages on the one hand and unfavourable public attitudes toward migration combined with anti-immigration political forces on the other. Both have, or are attempting to, resist high levels of migration, and yet both increasingly understand that future prosperity depends on access to labour migration. The increasing pace of globalization, new geopolitics and demographic changes in the contemporary world have accelerated population movements and brought new groups of migrants to both societies. As a consequence, both Japan and the UK are witnessing increasing diversification of their societies and face what Hall (2017:1024) has

(c) The Author(s). 2021 Open Access This article is licensed under a Creative Commons Attribution 4.0 International License, which permits use, sharing, adaptation, distribution and reproduction in any medium or format, as long as you give appropriate credit to the original author(s) and the source, provide a link to the Creative Commons licence, and indicate if changes were made. The images or other third party material in this article are included in the article's Creative Commons licence, unless indicated otherwise in a credit line to the material. If material is not included in the article's Creative Commons licence and your intended use is not permitted by statutory regulation or exceeds the permitted use, you will need to obtain permission directly from the copyright holder. To view a copy of this licence, visit http://creativecommons.org/licenses/by/4.0/. 
described as "a crisis of political imagination to engage with $21^{\text {st }}$ century citizenship". This special issue compares the migration and diversification experiences in the UK and Japan. Given the complexity of migration phenomena, both historically and at present, the issue collectively explores the utility of the concept of "superdiversity" for understanding diversification experiences in these two countries.

The term superdiversity has been invoked to describe the move from the predominance of "old" migration rooted in colonial and post-colonial relations, to "new" migration, wherein people arrive from many different countries as a result of shifting geopolitical circumstances. It also acknowledges the intra-group heterogeneity of migrant and minority populations. Vertovec's (2007) concept of superdiversity describes the "transformative diversification of diversity" (Vertovec, 2007: 1025) and associated demographic complexity driven by global and internal migration accompanied by other political, policy and socio-cultural changes. Despite some contestation (Back, 2015; Hall, 2017; Ndhlovu, 2016), superdiversity is acknowledged as both a demographic reality and as an analytical lens through which to describe multiple differentiations. Superdiversity is seen as offering considerable potential to fill the current postmulticulturalism theoretical void (Fomina, 2010) through providing a new lens to help develop understanding about the ways in which older and novel demographic complexities shape societies and how they can be governed.

However, regardless of increasing awareness and acceptance of superdiversity as a new demographic reality and the recognition that factors beyond ethnicity and country of origin play a major role in migrant settlement and social relations, migration studies have to some extent continued to be dominated by an ethno-national focus. Interactions between migrants, their descendants, established populations, employers and the state have tended to be analysed using binary language of them/us, minority/majority. This approach does not permit adequate analysis of the socio-cultural and demographic complexity that underpins migration and consequent superdiversity. Further with some important exceptions (ie Vertovec, 2015; Yeoh, 2018) the conceptual framework and methods required to research migration and resultant superdiversity developed within and outside of Europe have lacked an opportunity for intellectual exchange. This special issue contributes to filling this gap in knowledge by comparing migrations and associated processes of socio-demographic and cultural diversification in the UK and Japan. It examines different aspects of migration and diversification in these two countries from multiple disciplinary perspectives and using a wide range of methods and in so doing offers a range of conceptual advancements and empirical insights.

\section{Superdiversity and superdiversifications}

Vertovec's invocation of the term "super-diversity" appears first in relation to the London UK. While he describes the ethnic and country of origin diversity of the city as "remarkable", and indeed much of the later focus on superdiversity has been on people arriving from more places to more places, he considers such as a "one-dimensional appreciation of contemporary diversity" (Vertovec, 2007:1025). Subsequent work focusing on interactions in superdiverse neighbourhoods has raised questions about the common aspects of identity that unite or divide people (Grzymala-Kazlowska \& Phillimore, 2018; Wessendorf, 2013) with arguments made that factors such as age, gender, spatial proximity and immigration status may be more important than ethno-national identity. 
Recently superdiversity researchers have talked about the need to identify the difference or differences that make a difference to people's lives (Humphris, 2015).

The demographic trends originally identified by Vertovec in London, are now evident in urban areas in many other developed countries. The poor quality of demographic data frequently makes identifying and comparing superdiversity over time difficult. A key concern is the absence of a particular tipping point at which superdiversity is said to occur. We argue that superdiversity is the product of the interaction of multiple processes producing an unprecedented level of population diversity. Superdiversity emerges as an additional layer of complexity to existing and ongoing multiculturalism or, in Japan, multicultural co-existence, where multiculture represent the presence of discernible groups of individuals of similar ethno-national origins. Superdiversity in this special issue refers to migration driven diversifications. We contend that the diversification within diversity is a feature of many urban populations in the Global North and a key feature of post-modernity in both the UK and Japan. Thus we recognise that processes of diversification are themselves diverse and context and temporally specific.

There are however certain features of superdiversity that have been identified by scholars. These include super-mobility, and the scale, speed and spread of diversification processes. Valentine \& Sadgrove (2012) refer to the unprecedented levels of movement experienced by both individuals and within the places they reside as "supermobility". Super-mobility is driven by multiple modes of migration which include secondary migration: circular migration, and onward migration as well as internal migration around the country of migration. The speed of diversification varies by locality and, as Meissner \& Vertovec (2015) note, increase has, until the pandemic, been the dominant direction of change. In their most recent immigration publication, the OECD (2019) note that immigration flows are on the rise in most OECD countries including the UK and Japan. Speed of change has been viewed as problematic for social cohesion in areas that have little familiarity with diversity (Kaufman \& Harris, 2014) but may barely be noticed in areas with long histories of immigration (Pemberton \& Phillimore, 2018). The scale of increase is related to the speed of change although speed may be experienced differently depending on the diversity starting point of a country with clear differences in evidence between Japan and the UK. Fear of, change frequently attracts the attention of policymakers and is of pertinence in highly nationalistic countries. Igarashi and Laurence (2021) in this issue explore the ways in immigration diversity impacts on social attitudes towards migrants.

As Vertovec (2007) indicates more people have been migrating from more places to more places. The spread of diversity from inner city areas in global cities to more urban areas, suburbs and even some rural areas is also a feature of superdiversity. These diversifications often result from demand for labour but also result from immigration policy such as the refugee resettlement programmes discussed by Phillimore et al. (2021b; this special issue). Such trends lead to autochthonous populations encountering diversity for the first time but can also generate fragmentation of populations (Phillimore et al., 2021a) wherein groups based on ethno-national identities are less in evidence and small numbers of individuals or families from different countries reside in the same locale. A key development of the past decades in the industrialised world has been the differentiation of rights and entitlements between migrants of different immigration statuses and lengths of residence. This is particularly the case in both the UK 
and Japan where immigration policy has sought to achieve the dual goal of both controlling migration and meeting the demand for labour and used length of residence and/or access to welfare as tools to control flows. Looking across the multi-layering of old and new migrations, increased mobility, speed, scale, spread of diversification and fragmentation of some groups it is evident that increasing migration driven population complexity is a key feature of superdiversity which may be difficult to explore empirically especially when datasets tend to focus on long-standing groups of old migrants. Yet there is a growing body of research on superdiversity.

The original intention of superdiversity was to 'recognise the multi-dimensional shifts in migration patterns' (Meissner \& Vertovec, 2015: 541) but in a recent analysis of 325 publication across 21 disciplines Vertovec (2019) identifies seven ways in which the term had been invoked, describing some attempts as "highly misleading". The most popular is as a call for a methodological reassessment taking into account new multidimensional patterns while the second is as a demographic context to a study, describing it as a new condition. Building on ideas of a new condition the next most popular usage is as a means to explore other forms of complexity, arguably as a mechanism to respond to the call from Wimmer \& Glick Schiller, (2002) to eschew methodological nationalism. Within this special issue we offer all of these evocations but responding in particular to Vertovec's (2019:125) preferred usage of "the search for better ways to describe and analyse new social patterns, forms and identities arising from migrationdriven diversification".

As Vertovec (2019) notes superdiversity has been widely invoked. We identify four key areas of focus in the social sciences and humanities which directly respond to migration driven diversification processes. The first and very much dominant area is that of encounters. Here we see a predominance of anthropology (following Vertovec) in immersive efforts to understand the everyday reality of encounters in superdiverse spaces. The work of Wessendorf (2014), Wise (2009), Valentine (2008) and Neal et al. (2019) stand out in the focus on interactions in micro-spaces in coffee shops, restaurants, parks and leisure activities. Another important strand of encounter focused work has been developed by sociolinguists. Much theoretical development has resulted from analyses of language use in social spaces including classrooms, markets, family homes and shops (see Creese \& Blackledge, 2018). Jan Blommaert's work on linguistic landscapes also stands out as important as he observes translanguaging on signage and how this signifies processes of superdiversification. Yet this body of work has perhaps attracted the most condemnation from critics of superdiversity. Accusations have been made of downplaying inequalities and exclusion (Anthias, 2013) and the absence of critical questioning about the loci of power and agency (McGhee, 2008). These criticisms are addressed by Hall (2017) in her mooring of superdiversity to what she describes as a brutal migration milieu in which, as typified by the UK and Japan's bifurcated approach to immigration, states both desperately need migrants and introduce diversity-creating regimes which sort migrants around an ethos of subordination.

A further key focus closely related to encounters is that of place which connects with Vertovec's (2019) superdiversity as a backdrop to a study and a push-back against groupism. Biehl (2014) uses the neighbourhood arguing that at this scale space and difference have the potential to shape each other. Pottie-Sherman and Hiebert (2015) advance a notion of super-diversity in the suburbs. Phillimore and colleagues (2013) 
and Phillimore (2015) focus on the super-diverse neighbourhood using mixed methods to explore the ways in which a wide range of phenomena including belonging. Herein methodological advancements looking across places are important because they actively seek to address methodological nationalism. Further scholars use a place-based focus to problematise existing binaries of host/guest, them/us within place (Wessendorf \& Phillimore, 2019; Grzymala-Kazlowska \& Phillimore, 2018). Yet the vast majority of studies on superdiverse spaces are by Western scholars feeding directly into criticisms by Ndhlovu (2016) that superdiversity is both ahistorical and Western-centric. In shifting the gaze to Japan we hope to begin to address some of this critique.

As we note above, immigration policy lies behind some of the features of superdiversity. The advent of superdiversity has been described as a challenge for policy (Vertovec 2007; Phillimore, 2011) because of the complexity and mobility of associated populations. Some policy-oriented research has explicitly explored key issues around power and agency addressing McGhee's (2008) critique and drawing out the role of structure in shaping lifeworlds. Some scholars have focused on policymakers' and practitioners' responses to challenges of addressing superdiverse needs (Boccagni, 2015; Phillimore et al., 2019, 2021a) while others have sought to identify need within and between populations (Pemberton et al., 2019; Phillimore, 2015, 2017). Pemberton et al. (2019) and Phillimore et al. (2021) using a household survey to explore the ways in which residents in four countries address health concerns find that agency and access to resources are central to individual's ability to bricolage in order to address their concerns and show how lack of trust in public healthcare is a key driver of inequality to access. Hamed et al. (2020) highlight the inherent racism in healthcare provision underpin healthcare seeking behaviours viewed as problematic by policymakers. There is considerable potential to examine further the role of policy in superdiversity and within this special issue (Wakisaka and Cardwell, 2021; Sigona et al., 2021; Phillimore et al., 2021b) all offer perspectives on policy comparing UK and Japan.

A final theme speaks to several of the threads drawn out by Vertovec (2019) and is a focus on methods. As noted, superdiversity demands a shift beyond methodological nationalism. Goodson \& Grzymala-Kazlowska (2017) call for more participatory and multi-dimensional methods and with Phillimore et al. (2018) suggesting a shift away from sampling based on similarity (country of origin, migration status etc) to maximum diversity and respondent driven sampling selecting respondents on the basis of difference. The challenges of ensuring access and overcoming linguistic barriers are partially addressed through community and participatory approaches (Goodson \& GrzymalaKazlowska, 2017) but these rely heavily on small sample qualitative approaches. Perhaps the most promising way forward is the use of mixed methods and comparative approaches which enable identification of patterns and explanations of processes (i.e. Bradby et al., 2019; Phillimore et al., 2019, 2021a). Within this special issue we offer examples of wide-ranging methodological approaches some of which engage with large datasets (Igarashi and Laurence, 2021) or rely on working within places for the long durée (Hall et al., 2021; Drnovšek Zorko and Debnár, 2021; Wessendorf and Farrer, 2021).

\section{Migration and diversity in UK}

Patterns of migration to and from Japan and the United Kingdom up to the end of World War II were largely shaped by the economic, political, and legal effects of 
colonialism, imperial expansion and retraction, and geopolitical adjustments and frictions linked to them (Hirota et al., 2019). Often, but not exclusively, they occurred within the territorial boundaries of the empire and would in current parlance fall under the internal migration rubric. British colonial wars, the administration of colonies and slave trade where among the main drivers of colonial mobility and of migration-driven diversity. Besides intra-Empire mobilities and well before the world wars, Britain also experienced the settlement of immigrant communities, including religious minorities escaping persecution in continental Europe, in particular Huguenots from France in the early eighteenth century and Jews from Eastern Europe from the late nineteenth century had long lasting impact on British society. The arrival of Eastern European Jews, in particular, was met with hostility in some segments of British society and led to the British Parliament passing the first of numerous immigration acts that introduced more stringent requirements for entry and residence for foreigners (Hansen, 2000). In the twentieth century, the world war efforts led to a major restructuring of movement around the British Empire and towards Britain not only due to the extensive involvement of colonial subjects in multiple war fronts with huge sacrifice of lives, but also due to the redrawing of borders, the forced movements of populations within the Empire and the scarcity of workforce available in Britain due to military conscription. Following the end of the WW2, the decolonization process further transformed the movement of people within the by then shrinking Empire. Nonetheless, imperial geopolitics shaped migration patterns also during the decades of decolonisation, with migration towards the UK being largely from the Commonwealth area until the UK's accession to the European Union in early 1970s.

Post-war arrivals from the Commonwealth - mainly from the Caribbean, India, Pakistan, Nigeria and South Africa - significantly increased the presence on non-white residents in the main urban and industrial centres of the country. The process of demographic diversification was uneven and patchy. From the Indian subcontinent, the majority of immigrants arrived in Britain during the 1950s and 1960s. Although often lumped together as one group by white Britons, these newcomers in fact came from a variety of religious and ethnic backgrounds. They included Hindus from the Gujarat region of western India, Sikhs from the eastern Punjab region, and Muslims both from the west part of Pakistan and from East Pakistan, which became Bangladesh in 1971.

Whereas earlier immigration laws exclusively targeted individuals who were not British colonial subjects, from the 1962 Commonwealth Immigrants Act onwards, the UK's immigration policies have slowly eroded Commonwealth citizens' rights to enter (Hansen, 2000; Solomos, 1989). These culminated with the introduction of visas for Commonwealth citizens and restrictions on family reunification in the 1988 Immigration Act (Sales, 2007). Besides, legislation regulating entry, since the 1960s Britain developed a substantial body of race relations legislation. Various Race Relations Acts (1965, 1968, 1976 and 2000) provided a statutory basis for stamping out racial discrimination in employment and other areas.

Up to the 1990s, the UK's net migration was negative, with up to half of the incoming migrants holding a British passport, this changed with the introduction of restrictions on the acquisition of citizenship by Commonwealth subjects, which went hand in hand with a closer integration in the EU migration system. In the 1990s, public concerns with immigration were directed almost exclusively to the arrival of asylum seekers, later 
on with the EU enlargement to Central and Eastern Europe, concerns about intra-EU mobility in particular from Poland, Romania and Bulgaria joined those focussing on the arrival of forced migrants (Lessard-Phillips et al., 2019).

Although the increasing numbers of asylum seekers arriving in the UK has attracted perhaps the most media and political attention official estimates from the years 1991 to 2017 (Home Office, 2019), show that work and study are the main reasons for individuals to come to the UK. The number of people coming for family reunification, either accompanying or joining a family member, has remained relatively stable during that period with numbers of asylum seekers rising and then falling and then being supplemented with the introduction of refugee resettlement programmes.

From the end of WW2 until the early 2000s, the largest group of non-UK born residents in the UK was born in the Republic of Ireland. Lessard-Phillips et al. (2019)'s analysis of Census data shows how the profile of immigration has changed over the decades responding to macro-geopolitical events. For example, in the first census after WW2, the main countries of origin were Ireland, Poland, India, Germany, and Russia. Twenty years later, at the cusp of EU membership, colonial ties still play a major role in determining migration pathways, with India, Jamaica and Pakistan feature in the top-5 list. With the EU enlargement in 2000s and lifting of restrictions on citizens of new EU member states, Polish and Romanians made the top-5 list in 2011. Importantly, from a demographic perspective, they also occupy a prominent place in data on live births, pointing to a long term demographic impact on British society (Lessard-Phillips \& Sigona, 2019).

Following the 2016 Brexit referendum in which concerns about immigration and loss of control over national borders were at the forefront in the public debate, the country has witnessed a change in its migration outlook with the decline in arrivals from the $\mathrm{EU}$ (EU immigration) and the increase in departure of EU nationals (EU emigration) as well as a growth of immigration from outside the EU (ONS, 2020). The realignment of immigration policy with the new geopolitical reorientation of the country after Brexit, the so-called Global Britain project, plays out in the ongoing negotiations on trade agreements with key partners like Australia, Canada, Japan and India.

British political debate on migration post-2016 has increasingly looked at the Australia's point-based system as a model for immigration governance, however concerns have been raised on the transferability of this policy (Sumption, 2019), in particular as it may not cater for the full range of skills required by the British economy. As a consequence of Brexit and the end of EU freedom of movement, EU residents already in the UK have had to apply for permit to stay through the EU Settled Scheme. For EU citizens willing to move to the UK from 2021, the new immigration system applies, which is likely to significantly change the profile of new EU comers in the future. (Favell 2020; Benson, 2020).

In 2019 there were approximately 6.2 million people with non-British nationality living in the UK and 9.5 million people who were born abroad, over one third of them live in London. After London, the British regions with the highest proportions of their population born abroad were the South East (13.4\%), the West Midlands (13.9\%), the East of England (12.9\%), and the East Midlands (12.7\%).

There were around 994,000 British nationals living in other EU countries (excluding Ireland), while there were around 3.7 million EU nationals living in the UK. India 
(9.1\%), Poland (8.6\%) and Pakistan (5.8\%) were the main countries of birth for foreign born residents in the UK in 2019 (ONS, 2020).

Migration studies as a discreet field of studies in the UK is relatively recent, dating back to the 1980s. The prevalence of intra-Commonwealth mobility up until the 1980s meant that rather than focusing on migration systems and movement, greater emphasis was afforded to the challenges of settlement for British subjects from the Commonwealth, particularly through the lens of race relations. The arrival and settlement of racialized subjects in Britain and the social and political conflicts that it generated particularly in urban areas - the countryside will begin to host immigrants later - was the main impetuous behind the work being carried out within the framework of race relations from different epistemological stances. In the 1980s, the profile of migration to Britain changed in response to Britain's geopolitical realignment in the European Economic Community (EEC). This led also to a diversification of topics and geographical interests for migration research. The field of studies consolidated over time around a small number of academic journals and the beginnings of a focus on forced migration. These key journals had close connections with emerging research centres and clusters. In the 1990s, transnationalism, diaspora and movement linked to the dissolution of the Soviet Union and the end of the Cold War were at the centre of the debate. A decade later, following a wave of high-profile terrorist attacks carried out by Islamist organisations in US and European cities, and the beginning of the war on terror, issues such as securitisation and bordering as well the so-called "death of multiculturalism" (Berg \& Sigona, 2013; Gilroy, 2012; Vertovec \& Wessendorf, 2009) acquires a central place in the scholarly debate, leading to a shift of attention towards 'integration' (Grzymala-Kazlowska \& Phillimore, 2018), encouraged also by the EU research agenda and funding.

\section{Migration and diversity in Japan}

Post-war Japan had no significant immigration until the 1980s, and the rhetoric of immigration is still studiously avoided in Japanese politics (Roberts, 2018). Instead of immigration, the immediate post-war years saw the repatriation of hundreds of thousands of former colonial subjects back to Korea and Taiwan, and the emigration of Japanese nationals to South American countries continued into the 1970s. The defeat in World War II and the loss of the colonies thereafter also changed the discourse of Japanese national identity from a multi-ethnic empire to a racially homogeneous island country-a discourse embraced and promoted by the state as well as its business world (Yoshino, 1992). Japanese government and businesses attributed Japan's post-war economic miracle to the harmony resulting from its racial and cultural homogeneity.

For several decades after WWII, Japan rejected the notion of importing foreign workers in an attempt to hold onto its identity of a single-race nation. The 1989 Immigrant Control and Refugee Recognition Act, with the creation of categories of employment and resident visas, marked the transition of Japan into an immigrant receiving country. Japan's immigration policy, as Wakizaka and Cardwell (2021; this issue) point out, is characterized by its selectiveness and restrictiveness. It prioritizes attracting educated and skilled professionals and international students and has tried to limit the import of manual labour. 
The largest groups of immigrants the post-1989 immigration has brought into Japan are international students, trainees and technical interns, workers in varied skill categories-from engineers and cooks to entertainers, long-term residents-mostly migrants with Japanese descent, and spouses and dependents of Japanese nationals. Many of these migrants have changed visa categories and settled in Japan. According to Japan's Ministry of Justice (MOJ) statistics, by the end of 2019, nearly three million $(2,933,137)$ foreign residents were living in this island country, with $27 \%$ of them permanent residents (Ministry of Justice (MOJ), 2020). Although foreign residents were only $2.3 \%$ of the total population in Japan, its share has been increasing because, while the number of foreigners continues to rise, Japan's native population has been steadily declining. In addition, half a million people have gained Japanese citizenship since 1980 (Liu-Farrer, 2020).

Japan is likely to see more immigrants in the future. It is the world's oldest nation with $28 \%$ of its population aged over 65 . With birthrates stagnant for decades, the only conceivable source of workers is immigration. However, despite the need as well as the reality of immigration, Japan still does not have institutional frameworks for immigration. This resistance toward immigration is due to political elites' concerns that immigration is incompatible with its ethno-nationalist self-identity and that immigrants will disrupt the social order and its way of life (Liu-Farrer, 2020; Strausz, 2019). Reluctance toward admitting immigration is also seen in the lack of an integration policy. Japan's official discourse toward immigrant integration is "multicultural coexistence"-a social ideal first appeared in the mid-1990s in local municipalities with a large presence of immigrants and adopted by the Ministry of International Affairs and Communications in 2006 at the national level (Ministry of Internal Affairs and Communication (MIAC), 2006). Aiming for coexistence is not the same as truly embracing cultural and social differences, or recognizing that Japan is changing toward a diverse society along multiple dimensions. Japan needs a new lens through which to look at itself.

Despite Japan's official avoidance of the discourse of immigration and a relatively small immigrant population, the scholarship on Japan's immigration and immigrants has proliferated. In the course of over three decades, a substantial body of literature has emerged, encompassing different types of migrants as well as national groups' mobility and settlement experiences. Research on the returned ethnic Japanese from Latin America reports their economic precarity (e.g. Roth, 2002; Tsuda, 2003), circular migration patterns (von Baeyer, 2019) and identity dilemma (Tsuda, 2003). Studies of Filipino marriage migrants highlight the fragility of reproductive labour migration in the context of global inequality as well as the resilience of these women (e.g. Faier, 2009; Suzuki, 2003). The research on Chinese, the largest foreign population in Japan, emphasizes their transnational outlooks and cultural adaptation (Liu-Farrer, 2011). Literature on Nepalese migrants, on the other hand, report the historical continuity and networked nature of their migration processes (Kharel, 2016). Researchers have also paid special attention to the plight of trainees and technical interns (Kamibayashi, 2010; Liang, 2014) and of irregular migrants (Liu-Farrer, 2008: Takaya 2017: Kato, 2019). This body of research emphasizes that Japan's refusal to import manual workers despite its desperate need for them together with its draconian control of irregular migration have made these groups of migrants particularly vulnerable to exploitation and human rights violations. In addition, more recently, with the children of immigrants 
growing up, more studies on the second generation-their mobility trajectories, their sense of belonging and identity-have emerged (Celero, 2016; Liu-Farrer, 2020; von Baeyer, 2019). In short, there has been increased research on the various foreign communities living within Japanese society. This interest is fueled by population increases and the constant changes in immigrant landscapes on the one hand, and by the nature of immigration into Japan on the other. Scholarship on migration into Japan collectively demonstrates that immigration to Japan has been a pragmatic and at the same time problematic process produced by the country's persistent ambivalence toward ethnic diversity amidst urgent demands for foreign labour and global talent (Liu-Farrer, 2020; Strausz, 2019).

Theoretical influences have mostly been from the West to the East. Migration scholarship in Japan has sought insights from empirical research in North America, Australia and Europe and utilized in creative ways a range of theoretical and conceptual tools derived from western tradition to understand the migration phenomena unfolding in this ethno-nationalist society. Migration system theory (Kajita et al., 2005; Tajima, 2010), transnationalism perspectives (Liu-Farrer, 2011; Tajima, 2010; von Baeyer, 2019), and mobility research-a new line of inquiry that focuses on mobility itself (Hof, 2019), among others, have had strong influences on scholarly interpretation of migration in Japan. The conceptual and theoretical development stemming from Japan's migration experiences, on the other hand, has only begun to have an impact on wider migration research. This imbalance might relate to the recency of immigration scholarship in Japan. Nonetheless, the specific migration patterns and complexity of mobility processes taking place, where institutional frameworks for international migration and immigrant integration are yet to develop, have facilitated new conceptualizations and theorizations (Liu-Farrer \& Yeoh, 2018). As this issue demonstrates, the investigation of migration and integration taking place in an ethno-nationalist society such as Japan has particular relevance in a global context where policy as well as public opinion regarding immigration is hostile; anti-immigration has become the main platform of populist party politics; and more countries are embracing ethno-nationalism.

\section{Comparing migration and diversity in UK and Japan}

Thus the UK has considerable experience of large-scale labour migration but also offering refuge to forced migrants. Public attitudes have become increasingly anti-migrant with the UK seeking for many years to reduce integrational migration instead relying heavily on intra-EU mobility. In contrast, Japan has received much smaller numbers of migrants. Underpinned by varying degrees of ethno-nationalist ideology that is highly resistant to immigration although in the UK as a union of devolved nations expressing wide ranging attitudes and, where legislation allows, different approaches to migrant reception, both have a need for migrant labour. Japan's focus has been placed on temporary labour schemes such as the technical intern system wherein migrants plugged gaps in the labour market without the prospect of long-term residence, a policy that has failed to meet employers' demand. The UK has utilised free-movers from the European Union, and is already facing major labour shortages alongside a global pandemic that reduces the possibilities for labour market mobility. Despite these different histories Japan and the UK currently find themselves in a similar position. Post-Brexit the UK is faced with looking for migrant labour beyond Europe and increasingly acknowledging 
that labour migration will be essential for its future prosperity. In April 2019 Japan opened its doors to large scale labour migration for the first time and is likely to see its society further diversify. As an old migration, already diverse nation re-embracing labour migration, and a more ethnically homogenous nation, the UK and Japan have much to learn from each other.

Both Japan and the UK have seen an evolution in the demand for migrant labour, arrival of immigrants, public attitudes towards migration and the governance of immigration and integration. As such with different traditions of scholarship and shared challenges comparing and contrasting migration and diversity in the UK and Japan offers the prospect of new empirical, theoretical, methodological and policy knowledge and insight.

\section{Applicability of superdiversity to Japan}

As we note above the concept of superdiversity was introduced specifically in relation to London and has subsequently been used extensively in relation to the UK and to European urban, and to a much lesser extent, rural areas. With much of the UK and Europe having a long history of migration and a number of countries now conceiving of themselves as either countries of immigration or multicultural it is perhaps not surprising that the notion of superdiversity has become so widely utilised. But given Japan's different immigration flows, history and scale does the concept have any function to help contemporary patterns of diversification? By 2020, foreign nationals were merely $2.3 \%$ of the Japanese population and contemporary immigration did not take place at a substantial scale until the late 1980s. Compared to the UK where the foreign born population made up $14 \%$ of the total population with a continuous post-war flow of immigration, it might be a stretch to label current Japan as a superdiverse society-a concept created to describe the increasingly complex demographic composition brought by large-scale immigration. However, diversification brought by immigration is taking place in many urban and rural localities (e.g. Wessendorf and Farrer, 2021; this issue). The presence of visibly foreign residents who speak unfamiliar languages and demonstrate different social and cultural behaviours challenges the nation's racially homogeneous self-identity and necessitates the adjustment of its accustomed way of life. Japan has been confronting the task of integrating the increasing foreign residents, and searching for a new social ideal. We argue that superdiversity may provide such a conceptual tool. Meanwhile, by bringing in empirical phenomena and theoretical discussion of immigration and diversification processes unfolding in a strongly ethnonationalist society, Japan's immigration experiences bring new insights for the theoretical development in the field of migration.

Japan's multicultural coexistence programs rely on local governments to provide services to foreigners residing in their locales and to incorporate them into local communities (Aiden, 2011; Nagy, 2013; Tagmeyer-Pak, 2000). It is a culturally oriented program (Kibe, 2016). As the name implies, it presents its central issue of coexistence of people from different backgrounds as cultural difference. In practice, local governments' programs mostly focus on removing linguistic barriers for access to services and promoting appreciation of different cultures. Many city or ward offices provide multilingual services and offer free or affordable language lessons to foreign residents (Aiden, 2011). 
Academics have been critical of this framework, arguing that the multicultural coexistence discourse helps reinforce the myth of Japan's cultural homogeneity (Nagayoshi, 2011; Tai, 2007). Even though the newly proposed integration measures have dropped "multicultural", what coexistence connotes is an image of groups, presumably the Japanese and foreigners of different nationalities, coexisting as parallel units. It calls for an effort in mutual understanding and tolerance, but does nothing to challenge its ethnonational self-identity-the root of Japan's many institutional and social dilemmas in dealing with immigration (Liu-Farrer, 2020).

It is precisely against this stubborn adherence to a discourse of ethnonationalism that we attempt to introduce the concept of superdiversity, because, on the one hand, it prescribes a different perspective on the engineering of the society. The concept of superdiversity highlights the internal differences that are inherent in national society, such as age, gender, rural or urban, sexual orientation, physical (dis) abilities, legal statuses -the various differences that make a difference in people's lives (Humphris, 2015). Scholars on Japanese society have critiqued how the modern Japanese myth of cultural and racial homogeneity is constructed by othering ethnic minorities and marginalizing sexual minorities (Mackie, 2000; Weiner, 2009), and creating semi-citizenship (MorrisSuzuki, 2015). Bringing in the framework of superdiversity can challenge this discourse.

Moreover, superdiversity problematizes the coexistence model of integration. Although immigrants are still a small population in Japan, they already expose characteristics that have prompted the conceptualization of superdiversity (Vertovec, 2007). Immigrants in Japan are socio-economically stratified and racially as well as culturally diverse. They experience different legal and institutional constraints. Individuals within the same national group occupy drastically different structural positions. For example, the more than 66,000 Indonesians in Japan are internally differentiated not only by legal and social economic status- for example, technical interns versus professional workers, but also religion-Christians and Muslims with varied religiosity, ethnicityChinese or not, and which islands they come from. Such internal diversity cannot be captured by the coexistence measures which often broadly categorize people by nationality, and therefore posing potential challenges to policy and practices that aim to support and integrate them, as already seen in the context of UK (Pemberton et al., 2019; Phillimore, 2015, 2017). Superdiversity, as a conceptual tool, sensitizes policymakers and practitioners to this social reality.

Meanwhile, studying immigration and diversity issues in Japan, an ethnonationalist society, allows new insights into the processes and outcomes of diversification, as the comparative studies in this issue collectively demonstrate. The comparison between Japan and the UK reveals that social spaces are nested and sometimes paradoxical cultural practices can be observed. For example, in a west Tokyo neighbourhood of "emerging diversity", small immigrant-run businesses become the "third space" where active intercultural contacts take place, while in the immigrant shops in the superdiverse neighborhood in east London, such intercultural encounters are fleeting (Wessendorf and Farrer, 2021; this issue). At the same time, immigrant entrepreneurs in Japan have to conform to the general cultural expectation of drinking and socializing for eateries in order to create the space where intercultural encounter takes place.

Moreover, as most of the comparative cases in this issue highlight, while the UK and Japan differ in histories and trajectories of immigration, the two countries share the 
market-oriented logic of selective immigration policy (Wakizaka and Cardwell, 2021; this issue). Immigrants' shared structural positions in these two countries lead to their similar experiences as well as the native population's reaction towards them (Igarashi and Laurence, 2021; this issue). Studies in both Japan and the UK highlight how both immigrants' labour market positions and native populations' economic conditions affect xenophobic sentiments (Nagayoshi, 2011, Igarashi and Laurence, 2021; this issue). In both countries, infrastructures exist in producing and sustaining illegality (Sigona et al., 2021; this issue). These shared findings in comparative cases, on the one hand, affirm that the barriers to integration are inherent in an immigration context that have placed immigrants in structurally segmented labour market, echoing the call for the superdiversity discussion to take into account structural inequality that affects both immigrant experiences and the native-migrant relationship. On the other hand, some of the insights have first emerged from observing and theorizing immigration experiences and integration practices in Japan, showing that theoretical development in the field of migration needs new empirical cases in different social contexts.

This collection of papers examine comparatively migration and diversity in Japan and the UK. The articles adopts different methodological and epistemological approaches to achieve this task, ranging from theory development from case studies in Japan and the UK, to the examination of legal and policy frameworks governing migration and forced displacement, from the analysis of processes of racialization for white immigrants in the two contexts, to the comparative ethnographies of eateries in London and Tokyo and the spatiality of multicultural mixing.

\section{Structure of the special issue}

The nine papers included in this issue are jointly produced by researchers from the UK and Japan. They were selected from papers presented at the NODE symposium in December 2020 which brought together over 50 scholars in a bid to bring new insight to scholarship around migration and diversity from the UK and Japan. We have selected articles offering different disciplinary lenses and focusing on different aspects of migration and diversity. Topics covered include migrants' labour market integration, refugee resettlement, the incorporation of irregular migrants, urban and local community transformation, retirement migration, sedentarism, and how some key diversity indicators, e.g. race, play out in the social contexts of Japan and the UK.

The special issue opens with an article by Igarashi and Laurence (2021) which explores how increasing diversification is affecting people's attitudes towards immigration in general. Engaging with the diversification of diversity the paper also examines whether the dynamics of changing immigration are affecting all individuals equally, or whether particular groups' social attitudes exhibit greater sensitivity to increasing immigration than others. This comparative analysis offers original insights into how (and amongst whom) Japan's demographic transition is impacting attitudes towards immigration, and how such processes operate in the UK. Our next paper authored by Drnovšek Zorko and Debnár (2021), deploys a comparative lens to interrogate how race plays out differently in diverse contexts of migration by exploring the contemporary racialization of white migrants in the UK and Japan. Focusing on the case of Eastern European migrants, they account for how local historical contexts shape the race and migration nexus beyond the framework of post-coloniality developed in primarily 
Western societies, contributing to debates that problematize whiteness as a universal or ahistorical property. In so doing the authors address directly the criticisms outlined above around a perceived lack of attention in the superdiversity literature to how race and history affect complexity of migrants' social positions within receiving societies. They show how race and history matter in spite of individuals' diverse subject positions. They further argue that paying attention to the experiences of migrants within different national contexts reveals that the identity of migrants and of the dominant group are both racialized.

The next paper adopts a policy focus. Wakizaka and Cardwell (2021) explore the various reforms of migration law and policy in the two countries highlighting the bifurcated approach adopted in each favouring highly skilled migrants and resisting lowskilled migration, despite an evident need for both. They argue that rather than Japan and the UK representing a 'Western' and 'Asian' model of migration, they are in fact examples of a market-driven model but one which enables migration to be 'sold' to often hostile publics. Since highly skilled migration is generally not politically contentious, policymakers in both countries avoid the need to have more widespread debate about other aspects of migration policy, including unskilled migration and family reunification.

The paper that follows responds to the need to contemplate the role of structure in the diversification of diversity. Sigona et al. (2021) brings together two bodies of migration scholarship by drawing on critical work on the social and legal production of illegality and the impact of legal violence on the lives of illegalised immigrants and the role of migrant infrastructures in shaping mobility pathways and entry, settlement and exit opportunities for migrants. The paper examines the diverse pathways leading migrants move into irregular status and why/how decisions are made, in some circumstances and under constrained options, to move into irregularity. They conceptualise migrants' agency in terms of integration accounting for both the practices through which migrants actively become political subjects and those that constitute a deliberate refusal to do so. Through examination of the infrastructures for the 'production' of 'illegality' including legal and policy instruments and their implementation by public and private operators they argue that despite structural differences, hostile environments and racism affect the production of 'illegality' and everyday lives of migrants in both countries.

Our next paper adds to the encounters genre in superdiversity research and is based on findings from two long-term place-based ethnographic neighbourhood studies in Tokyo and London. In both cases, migrant restaurants serve as 'culinary contact zones' for many and 'third places' for some regular customers. The authors argue the need to pay greater attention to the role of established cultural norms of interaction in specific third places highlighting the importance of understanding the nature of the superdiverse context. In the following paper Phillimore et al. (2021b) shift the focus to refugee resettlement policy and specifically how distinctive Japanese and UK approaches to resettlement and integration shape integration outcomes. Like Wessendorf and Farrer (2021) they note the importance of cultural context with a key dimension shaping integration outcomes in the form of the experience of Japanese firms or UK communities of encountering diversity. They contend that while there are distinct differences in the policy, practice and cultural contexts underpinning both approaches to resettlement, 
understanding the strengths and weaknesses of each scheme can bring new knowledge about how to support refugee integration in refugee resettlement programmes more generally.

Our final papers bring a new perspective to migration research. The first by Hall et al. (2021) looks outwards at the emigration of 'third age' migrants from the UK to Spain and Japan to Malaysia. In both contexts, migrants tended to move into already established ethnic communities and maintain transnational ties with the homeland. They find that although migrants are not fully integrated locally, they fabricate their everyday lives with local encounters and resources generating complex social and support networks often constructed over national borders. They extend the concept of bricolage to explore the barriers and constraints faced by migrants as they negotiate the obstacles arising as they age away from the home country. Hof et al. (2021) shift emphasis from mobility to staying arguing that this an active agent-centred process, and which is often an integral element of a life strategy involving other people or places. Using the concept of 'differentiated embedding' (Ryan, 2018) they highlight the place-specific, relational, transnational, temporal and more individualised processes which shape staying. Again emphasizing the importance of considering the diversification of diversity and local context they highlight the key role of linguistic proficiency, social networks and familiarity with local and extra-local infrastructure as well as enhanced access to housing and employment opportunities.

\section{Abbreviation \\ UK: United Kingdom}

\section{Acknowledgements}

The authors are grateful for financial support of the ESRC and Japan Foundation, Waseda University and the University of Birmingham without which the NODE network would not exist. Their generous contributions enabled multiple scholars to meet, collaborate and contribute to the special issue. Without this opportunity the special issue would not be possible.

\section{Authors' contributions}

Jenny Phillimore led the NODE UKJJapan Network and the drafting of the overall article. Gracia Liu-Farrer is CoInvestigator of the network and Japan lead. She drafted all the material on Japan. Nando Sigona is Co-Investigator of the network and drafted all the material on migration in the UK and on migration scholarship in the UK. All authors contributed extensively to the editing of the article and have read and approved the final manuscript.

\section{Funding}

The NODE UK/Japan Network which has produced this special issue is funded by the Economic and Social Research Council Grant number ES/S013245/1 and the Japan Foundation 2019RE421.

Availability of data and materials

Not applicable.

\section{Declaration}

\section{Competing interests}

The authors declare that they have no competing interests.

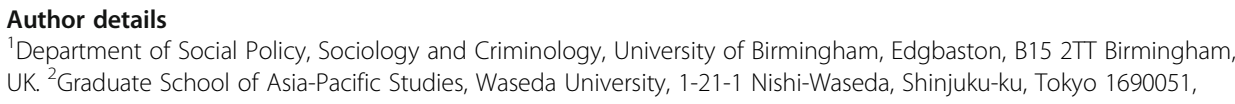


Anthias, F. (2013). Moving beyond the Janus face of integration and diversity discourses: Towards an intersectional framing. The Sociological Review, 61(2), 323-343. https://doi.org/10.1111/1467-954X.12001.

Back, L. (2015). Losing culture or finding superdiversity. Retrieved from: https://discoversociety.org/2015/05/05/losing-cultureor-finding-superdiversity-2/

Benson, M., 2020. Brexit and the classed politics of bordering: the British in France and European belongings. Sociology, 54(3), 501-517.

Berg, M. L., \& Sigona, N. (2013). Introduction: Ethnography, diversity and urban space. Identities: Global Studies in Culture and Power, 20(4), 347-360. https://doi.org/10.1080/1070289X.2013.822382.

Biehl, K. S. (2014). Exploring migration, diversification and urban transformation in contemporary Istanbul: The case of Kumkapı (MMG Working Paper 14-11). Göttingen: Max Planck Institute for the Study of Religious and Ethnic Diversity.

Boccagni, P. (2015). (Super) diversity and the migration-social work nexus: A new lens on the field of access and inclusion? Ethnic and Racial Studies, 38(4), 608-620. https://doi.org/10.1080/01419870.2015.980291.

Bradby, H., Thapar-Björkert, S., Hamed, S., \& Ahlberg, B. M. (2019). Undoing the unspeakable: Researching racism in Swedish healthcare using a participatory process to build dialogue. Health Research Policy and Systems, 17(1), 43. https://doi.org/1 0.1186/s12961-019-0443-0.

Celero, J. O. 2016. Japanese-Filipinos' transnational pathways to social mobility: Education, occupation and life aspirations (Dissertation submitted to Graduate School of Asia-Pacific Studies). Waseda Universtiy.

Creese, A., \& Blackledge, A. (2018). The Routledge handbook of language and superdiversity. Routledge. https://doi.org/10.4324/ 9781315696010.

Drnovšek Zorko, Š., \& Debnár, M. (2021). Comparing the racialization of Central-East European migrants in Japan and the UK. Comparative Migration Studies, 9. https://doi.org/10.1186/s40878-021-00239-z.

Faier, L. (2009). Intimate encounters: Filipina women and the remaking of rural Japan. Univ of California Press. https://doi.org/1 $0.1525 / 9780520944596$.

Fomina, J. (2010). Immigration policy debates and their significance for multiculturalism in Britain. Polish Sociological Review, $169,57-86$.

Gilroy, P. (2012). 'My Britain is fuck all' zombie multiculturalism and the race politics of citizenship. Identities, 19(4), 380-397.

Goodson, L., \& Grzymala-Kazlowska, A. (2017). Researching migration in a Superdiverse society: Challenges, methods, concerns and promises. Sociological Research Online, 22(1), 15-27. https://doi.org/10.5153/sro.4168.

Grzymala-Kazlowska, A., \& Phillimore, J. (2018). Introduction: Rethinking integration. New perspectives on adaptation and settlement in the era of super-diversity. Journal of Ethnic and Migration Studies, 44(2), 179-196. https://doi.org/10.1080/13 69183X.2017.1341706.

Hall, S. M. (2017). Mooring "super-diversity" to a brutal migration milieu. Ethnic and Racial Studies, 40(9), 1562-1573. https:// doi.org/10.1080/01419870.2017.1300296.

Hall, K., Ono, M., \& Kohno, A. (2021). British and Japanese international retirement migration and creative responses to health and care challenges: a bricolage perspective. Comparative Migration Studies, 9. https://doi.org/10.1 186/s40878-020-00217-x.

Hamed, S., Thapar-Björkert, S., Bradby, H. and Ahlberg, B.M., 2020. Racism in European health care: structural violence and beyond. Qualitative health research, 30(11), 1662-1673.

Hansen, R. (2000). Citizenship and immigration in postwar Britain. USA: Oxford University Press.

Favell, A., 2020. Here, there and everywhere: nationalism after Brexit. Ethnic and Racial Studies, 43(8), 1446-1452.

Hirota, H., Sigona, N., \& Nagai, N. (2019). Migration to and from Japan and Great Britain to 1945 (IRiS working paper series, no. 33/2019). Birmingham: Institute for Research into Superdiversity.

Hof, H. (2019). The Eurostars go global: Young Europeans' migration to Asia for distinction and alternative life paths. Mobilities, 14(6), 923-939. https://doi.org/10.1080/17450101.2019.1643164.

Hof, H., Pemberton, S., \& Pietka-Nykaza, E. EU migrant retention and the temporalities of migrant staying: a new conceptual framework. Comparative Migration Studies, 9. https://doi.org/10.1186/s40878-021-00225-5.

Home Office (2019) Immigration statistics, year ending June 2019, second edition. Retrieved from https://www.gov.uk/ government/statistics/immigration-statistics-year-ending-june-2019

Humphris, R. (2015). Intersectionality and superdiversity: What's the difference. Birmingham: University of Birmingham, Institute for Research into Superdiversity (IRiS).

Igarashi, A., \& Laurence, J. (2021). How does immigration affect anti-immigrant sentiment, and who is affected most? A longitudinal analysis of the UK and Japan cases. Comparative Migration Studies, 9. https://doi.org/10.1186/s40878-021$00231-7$.

Kajita, T., Tanno, K., \& Higuchi, N. (2005). Kaono Mienai Teijyūka: Nik- kei Burajirujin to Kokka, Shijyō, Imin Nettowaku [Invisible residents, Japanese Brazilians Vis-à-Vis the states, the market and the immigrant network]. Nagoya: University of Nagoya Press.

Kamibayashi, C. (2010). The temporary foreign worker Programme in Japanese style: The 20 years' history of the technical internship Programme (TIP). (Working paper, Institute of Comparative Economic Studies). Tokyo: Hosei University.

Kato Jotaro. 2019. Fuhōsei to tomoni ikiru: Hiseiki taizaisha ga nihon de kurasukoto wo kanō to suru yōyin ha nanika [Live with 'illegality': What makes it possible for irregular migrants to live in Japan]. Imin seisaku kenkyü (Immigration Policy Research), 11, 60-74.

Kaufman, E., \& Harris, G. (2014). Changing places: Mapping the white British response to ethnic change. London: Demos.

Kharel, D. (2016). From Lahures to global cooks: Network migration from the Western Hills of Nepal to Japan. Social Science Japan Journal, 19(2), 173-192. https://doi.org/10.1093/ssjj/jyw033.

Kibe, T. (2016). The 'multicultural coexistence' discourse in crisis? Public discourse on immigrant integration in the gap society. In D. Chiavacci, \& C. Hommerich (Eds.), Social inequality in post-growth Japan: Transformation during economic and demographic stagnation (pp. 250-265). London: Routledge.

Lessard-Phillips, L., Roberts, G., \& Phillimore, J. (2019). Policy and politics of migration post-1945 (IRiS working paper series, no. 34/2019). Birmingham: Institute for Research into Superdiversity. 
Lessard-Phillips, L, Sigona, N (2019). UK-born children of EU nationals in the UK (Eurochildren Research Brief Series, no.5). Retrieved from https://eurochildrenblog.files.wordpress.com/2019/06/eurochildren-uk-born-children-of-eu-nationals-inthe-uk-historical-national-and-local-perspectives.pdf

Liang Meng. 2014. Seasonal labour migration of Chinese agricultural workers to Kawakami Village: Migrant realities, negotiations, and a collaborative power network (2014) (Dissertation submitted to Department of East Asian Studies, Cambridge University). Cambridge University.

Liu-Farrer, G. (2008). The burden of social capital: Fujian Chinese immigrants' experiences of network closure in Japan. Social Sci Japan J, 11(22), 241-257. https://doi.org/10.1093/ssjj/jyn035.

Liu-Farrer, G. (2011). Labor migration from China to Japan: International students, transnational migrants. London: Routledge.

Liu-Farrer, G., Brenda S., Yeoh A. (2018). Asian Migrations and Mobilities: Continuities, Conceptualisations and Controversies. In G. Liu-Farrer and B. Yeoh (Eds.), Routledge Handbook of Asian Migrations (1-18). London: Routledge.

Liu-Farrer, G. (2020). Immigrant Japan: Mobility and belonging in an ethno-nationalist society. Ithica: Cornell University Press.

Mackie, V. (2000). The dimensions of citizenship in modern Japan: Gender, class, ethnicity and sexuality, Citizenship and democracy in a global era (pp. 245-257).

McGhee, D. (2008). End of multiculturalism: Terrorism, integration and human rights. New York: McGraw-Hill Education.

Meissner, F., \& Vertovec, S. (2015). Comparing super-diversity. Ethnic and Racial Studies, 38(4), 541-555. https://doi.org/10.1080/ 01419870.2015 .980295$.

Ministry of Internal Affairs and Communication (MIAC). (2006). Tabunnka kyōsei no suishin ni kansuru kenkyūkai hōkokusho [Research Council Report about the Promotion of Multicultural Coexistence]. Retrieved December 13, 2020, from https:// www.soumu.go.jp/kokusai/pdf/sonota_b5.pdf.

Ministry of Justice (MOJ). Zairyū gaikokujin tōkei [Statistics of Foreign residents]. Retrieved December 13, 2020, from https:// www.e-stat.go.jp/stat-search/files?page $=1 \&$ layout=datalist\&toukei $=00250012 \&$ tstat $=000001018034 \&$ cycle $=1 \& y e a r=201$ 90\&month $=24101212 \&$ tclass $1=000001060399$.

Morris-Suzuki, T. (2015). Beyond racism: Semi-citizenship and marginality in modern Japan. Japanese Studies, 35(1), 67-84. https://doi.org/10.1080/10371397.2015.1014469.

Nagayoshi, K. (2011). Support of multiculturalism, but for whom? Effects of ethno-national identity on the endorsement of multiculturalism in Japan. Journal of Ethnic and Migration Studies, 37(4), 561-578. https://doi.org/10.1080/1369183X.2011. 545272.

Nagy, S. (2013). Multicultural coexistence policies of local governments in the Tokyo Metropolis: A comparative examination of social integration in response to growing ethnic diversity. In A. E. Lai, F. L. Collins, \& B. S. A. Yeoh (Eds.), Migration and diversity in Asian contexts, (pp. 54-82). Singapore: IS- EAS Publishing.

Ndhlovu, F. (2016). A decolonial critique of diaspora identity theories and the notion of superdiversity. Diaspora Studies, 9(1), 28-40. https://doi.org/10.1080/09739572.2015.1088612.

Neal, S., Bennett, K., Cochrane, A., \& Mohan, G. (2019). Community and conviviality? Informal social life in multicultural places. Sociology, 53(1), 69-86. https://doi.org/10.1177/0038038518763518.

OECD (2019) OECD international migration database and labour market outcomes of immigrants. Retrieved September 9, 2020, from https://www.oecd.org/els/mig/keystat.htm.

ONS (2020) Migration statistics quarterly report: August 2019. Retrieved from https://www.ons.gov.uk/peoplepopulationa ndcommunity/populationandmigration/internationalmigration/bulletins/migrationstatisticsquarterlyreport/august2020.

Pemberton, S., \& Phillimore, J. (2018). Migrant place-making in super-diverse neighbourhoods: Moving beyond ethno-national approaches. Urban Studies, 55(4), 733-750. https://doi.org/10.1177/0042098016656988.

Pemberton, S., Phillimore, J., Bradby, H., Padilla, B., Lopes, J., Samerski, S., \& Humphris, R. (2019). Access to healthcare in superdiverse neighbourhoods. Health \& Place, 55, 128-135. https://doi.org/10.1016/j.healthplace.2018.12.003.

Phillimore, J. (2011). Approaches to health provision in the age of super-diversity: Accessing the NHS in Britain's most diverse city. Critical Social Policy, 31(1), 5-29. https://doi.org/10.1177/0261018310385437.

Phillimore, J. (2013). Housing, home and neighbourhood renewal in the era of superdiversity: Some lessons from the West Midlands. Housing Studies, 28(5), 682-700.

Phillimore, J. (2015). Delivering maternity services in an era of superdiversity: The challenges of novelty and newness. Ethnic and Racial Studies, 38(4), 568-582. https://doi.org/10.1080/01419870.2015.980288.

Phillimore, J. (2017). Migrant maternity in an era of superdiversity: New migrants' access to, and experience of, antenatal care in the west midlands, UK. Social Science \& Medicine, 148, 152-159. https://doi.org/10.1016/j.socscimed.2015.11.030.

Phillimore, J., Bradby, H., \& Brand, T. (2019). Superdiversity, population health and health care: Opportunities and challenges in a changing world. Public Health, 172, 93-98. https://doi.org/10.1016/j.puhe.2019.01.007.

Phillimore, J., Bradby, H., Brand, T., Padilla, B., \& Pemberton, S. (2021a). Exploring welfare bricolage in Europe's Superdiverse Neighbourhoods. Routledge. https://doi.org/10.4324/9781003111504.

Phillimore, J., Morrice, L., Kabe, K., Hashimoto, N., Hassan, S., \& Reyes, M. (2021b). Economic self-reliance or social relations? What works in refugee integration? Learning from resettlement programmes in Japan and the UK. Comparative Migration Studies, 9. https://doi.org/10.1186/s40878-021-00223-7.

Phillimore, J., Bradby, H., Doos, L., Padilla, B., \& Samerski, S. (2018). Health providers as bricoleurs: An examination of the adaption of health ecosystems to superdiversity in Europe. Journal of European Social Policy, 29(3), 361-375. https://doi. org/10.1177/0958928718795994.

Pottie-Sherman, Y. and Hiebert, D., 2015. Authenticity with a bang: Exploring suburban culture and migration through the new phenomenon of the Richmond night market. Urban Studies, 52(3), 538-554.

Roberts, G. (2018). An immigration policy by any other name: Semantics of immigration to Japan. Social Science Japan Journal, 21(1), 89-102. https://doi.org/10.1093/ssjj/jyx033.

Roth, J. H. (2002). Brokered homeland: Japanese Brazilian migrants in Japan. Ithaca: Cornell University Press.

Ryan, L., (2018). Differentiated embedding: Polish migrants in London negotiating belonging over time. Journal of Ethnic and Migration Studies, 44(2), 233-251.

Sales, R. (2007). Understanding immigration and refugee policy: Contradictions and continuities. Bristol: Policy Press. https://doi. org/10.2307/j.ctt1t88zm3. 
Sigona, N., Kato, J., \& Kuznetsova, I. (2021). Migration infrastructures and the production of migrants' irregularity in Japan and the United Kingdom. Comparative Migration Studies, 9. https://doi.org/10.1186/s40878-021-00242-4.

Solomos, J. (1989). The politics of immigration since 1945. In J. Solomos (Ed.), Race and racism in contemporary Britain (pp. 40-67). London: Macmillan Education UK. https://doi.org/10.1007/978-1-349-20187-7_3.

Strausz, M. (2019). Help (not) wanted: Immigration politics in Japan. Albany: SUNY Press.

Sumption, M (2019). The Australian points-based system: What is it and what would its impact be in the UK? UK in a Changing Europe Blog. Retrieved from https://ukandeu.ac.uk/the-australian-points-based-system-what-is-it-and-what-would-its-impa ct-be-in-the-uk/

Suzuki, N. (2003). Transgressing "victims" reading narratives of "Filipina brides" in Japan. Critical Asian Studies, 35(3), $399-420$. https://doi.org/10.1080/1467271032000109908.

Tagmeyer-Pak, K. T. (2000). Foreigners are local citizens, too: Local governments respond to international migration in Japan, Japan and global migration: Foreign workers and the advent of a multicultural society (pp. 243-274).

Tai, E. (2007). Multicultural Education in Japan. Asia-Pacific Journal-Japan Focus, 5(12), 1-20. https://apjjf.org/-Eika-TAl/2618/a rticle.pdf.

Tajima, J. (2010). Kokusai ljyū no Shakaigaku - Higashi Ajia no Gurōbaruka wo Kangaeru [Sociology of international migration: Thinking about the east Asian globalization]. Tokyo: Akashi Shoten.

Takaya, S. (2017) Tsuihō to Teikō no poritikusu: Sengo Nihon no Kyokai to Hiseiki Imin [Politics of Deportation and Resistance: Boundary and Irregular Migrants in the Post War Japan]. Kyoto: Nakanishiya Shuppan.

Tsuda, T. (2003). Strangers in the ethnic homeland: Japanese Brazilian return migration in transnational perspective. New York: Columbia University Press. https://doi.org/10.7312/tsud12838.

Valentine, G. (2008). Living with difference: Reflections on geographies of encounter. Progress in Human Geography, 32(3), 323-337. https://doi.org/10.1177/0309133308089372.

Valentine, G., \& Sadgrove, J. (2012). Lived difference: A narrative account of spatiotemporal processes of social differentiation. Environment and Planning A: Economy and Space, 44(9), 2049-2063. https://doi.org/10.1068/a44491.

Vertovec, S. (2007). Super-diversity and its implications. Ethnic and Racial Studies, 30(6), 1024-1054. https://doi.org/10.1080/ 01419870701599465.

Vertovec, S. 2015. Diversities old and new: Migration and socio-spatial patterns in New York. Singapore and Johannesburg. Springer.

Vertovec, S. (2019). Talking around super-diversity. Ethnic and Racial Studies, 42(1), 125-139. https://doi.org/10.1080/0141 9870.2017.1406128.

Vertovec, S., \& Wessendorf, S. (Eds.) (2009). The multiculturalism backlash, European Discourses, Policies and Practice. Palgrave.

von Baeyer, S.A.L., 2019. Living transnationally between Japan and Brazil: Routes beyond roots. Lexington Books.

Wakisaka, D., \& Cardwell P. J. (2021). Exploring the trajectories of highly skilled migration law and policy in Japan and the UK. Comparative Migration Studies, 9. https://doi.org/10.1186/s40878-021-00251-3.

Weiner, M. (2009). 'Self' and 'other' in imperial Japan, Japan's minorities: The illusion of homogeneity (pp. 1-20). London: Routledge.

Wessendorf, S. (2013). Commonplace diversity and the 'ethos of mixing': Perceptions of difference in a London neighbourhood. Identities, 20(4), 407-422. https://doi.org/10.1080/1070289X.2013.822374.

Wessendorf, S. (2014). 'Being open, but sometimes closed'. Conviviality in a super-diverse London neighbourhood. European Journal of Cultural Studies, 17(4), 392-405. https://doi.org/10.1177/1367549413510415.

Wessendorf, S., \& Farrer, J. (2021). Commonplace and out-of-place diversities in London and Tokyo: migrant-run eateries as intercultural third places. Comparative Migration Studies, 9. https://doi.org/10.1186/s40878-021-00235-3.

Wessendorf, S., \& Phillimore, J. (2019). New migrants' social integration, embedding and emplacement in Superdiverse contexts. Sociology, 53(1), 123-138. https://doi.org/10.1177/0038038518771843.

Wimmer, A., \& Glick Schiller, N. (2002). Methodological nationalism and beyond: Nation-state building, migration and the social sciences. Global networks, 2(4), 301-334. https://doi.org/10.1111/1471-0374.00043.

Wise, A. (2009). Everyday multiculturalism: Transversal crossings and working class cosmopolitans. In everyday multiculturalism (pp. 21-45). London: Palgrave Macmillan.

Yeoh, B.S., 2018. Transnational migrations and plural diversities: Encounters in global cities. In Routledge handbook of Asian migrations (pp. 238-249). Routledge.

Yoshino, K. (1992). Cultural nationalism in contemporary Japan: A sociological enquiry. London: Routledge.

\section{Publisher's Note}

Springer Nature remains neutral with regard to jurisdictional claims in published maps and institutional affiliations. 